\title{
Impacts of Biodiesel Fuel Blends Oil Dilution on Light-Duty Diesel Engine Operation
}

Conference Paper NREL/CP-540-44833

August 2009

M.J. Thornton, T.L. Alleman, J. Luecke, and R.L. McCormick

Presented at the 2009 SAE International Powertrains, Fuels, and Lubricants Meeting

Florence, Italy

June 15-17, 2009
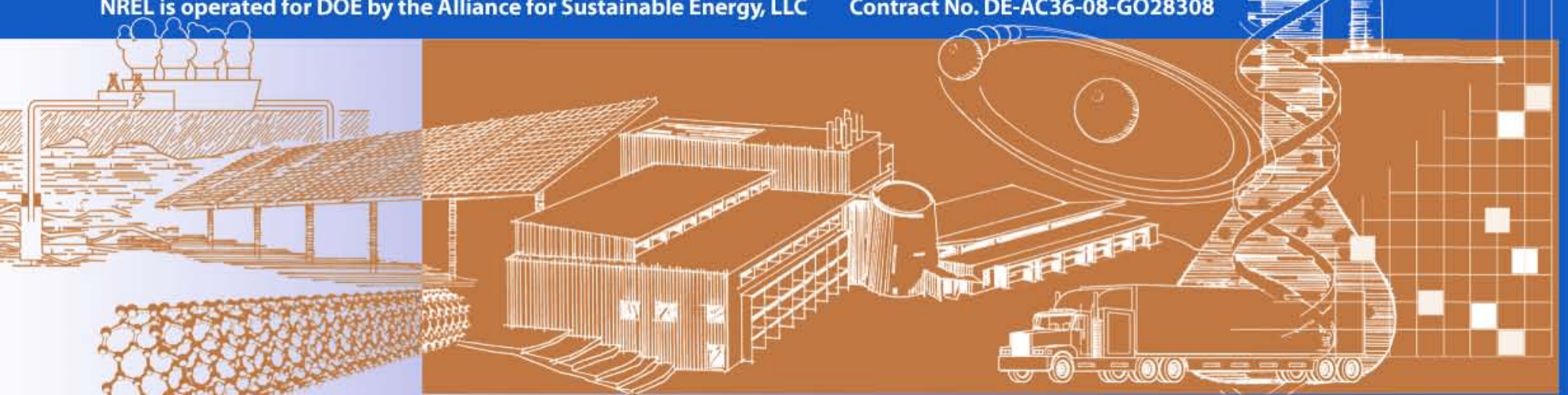


\section{NOTICE}

The submitted manuscript has been offered by an employee of the Alliance for Sustainable Energy, LLC (ASE), a contractor of the US Government under Contract No. DE-AC36-08-GO28308. Accordingly, the US Government and ASE retain a nonexclusive royalty-free license to publish or reproduce the published form of this contribution, or allow others to do so, for US Government purposes.

This report was prepared as an account of work sponsored by an agency of the United States government. Neither the United States government nor any agency thereof, nor any of their employees, makes any warranty, express or implied, or assumes any legal liability or responsibility for the accuracy, completeness, or usefulness of any information, apparatus, product, or process disclosed, or represents that its use would not infringe privately owned rights. Reference herein to any specific commercial product, process, or service by trade name, trademark, manufacturer, or otherwise does not necessarily constitute or imply its endorsement, recommendation, or favoring by the United States government or any agency thereof. The views and opinions of authors expressed herein do not necessarily state or reflect those of the United States government or any agency thereof.

Available electronically at http://www.osti.gov/bridge

Available for a processing fee to U.S. Department of Energy and its contractors, in paper, from:

U.S. Department of Energy

Office of Scientific and Technical Information

P.O. Box 62

Oak Ridge, TN 37831-0062

phone: 865.576.8401

fax: 865.576 .5728

email: mailto:reports@adonis.osti.gov

Available for sale to the public, in paper, from:

U.S. Department of Commerce

National Technical Information Service

5285 Port Royal Road

Springfield, VA 22161

phone: 800.553.6847

fax: 703.605.6900

email: orders@ntis.fedworld.gov

online ordering: http://www.ntis.gov/ordering.htm 


\title{
Impacts of Biodiesel Fuel Blends Oil Dilution on Light-Duty Diesel Engine Operation
}

\author{
Matthew J. Thornton, Teresa L. Alleman, Jon Luecke, and Robert L. McCormick \\ National Renewable Energy Laboratory
}

\begin{abstract}
Increasing interest in biofuels-specifically, biodiesel as a pathway to energy diversity and security-has necessitated the need for research on the performance and utilization of these fuels and fuel blends in current and future vehicle fleets. One critical research area is related to achieving a full understanding of the impact of biodiesel fuel blends on advanced emission control systems. In addition, the use of biodiesel fuel blends can degrade diesel engine oil performance and impact oil drain interval requirements.
\end{abstract}

There is limited information related to the impact of biodiesel fuel blends on oil dilution. This paper assesses the oil dilution impacts on an engine operating in conjunction with a diesel particle filter (DPF), oxides of nitrogen $\left(\mathrm{NO}_{\mathrm{x}}\right)$ storage, a selective catalytic reduction (SCR) emission control system, and a $20 \%$ biodiesel (soy-derived) fuel blend. The main focus was on the biodiesel oil dilution levels observed during an accelerated aging protocol and an assessment of the potential impacts on the engine and emissions control systems. For the $\mathrm{NO}_{x}$ storage system (which requires a late in-cylinder fuel injection for regeneration), biodiesel oil dilution levels ranged from $5 \%-10 \%$. For the SCR system (which used a urea solution as a reductant and late in-cylinder fuel injection for diesel particle filter regeneration), biodiesel oil dilution ranged from $<4 \%-8 \%$. These observations were made over typical oil drain intervals. Despite these observed biodiesel oil dilution levels, there were no observed impacts on the performance of the engine or the emission control systems.

\section{INTRODUCTION}

Biodiesel fuel blends are one option currently being researched as a pathway to energy diversity and reduced petroleum dependence in the transportation sector. One of the key factors related to the success of biodiesel fuel blends is their compatibility with vehicle components such as fuel systems, combustion parts, and advanced emission control systems. However, one way that biodiesel fuel blends can create potential problems affecting vehicle operation is through accelerated dilution of the oil by the fuel. This is particularly important for vehicles utilizing advanced emissions control systems that require late in-cylinder fuel injection. Excessive oil dilution has the potential to lead to several problems, such as reduced oil performance and durability (e.g., decreased viscosity or the development of oil sludge) and catalyst poisoning. At a minimum, oil dilution could impact the interval requirements for oil changes, the effectiveness of additive packages, and sump capacity. Acceptable oil dilution limits for original equipment manufacturers (OEMs) range up to $50 \%$ [1], but most OEMs want limits to be much lower.

Biodiesel is a renewable fuel derived from vegetable oil, animal fat, or waste cooking oil, and it consists of the methyl esters of fatty acids. It is typically used as a diesel blending component at levels up to $20 \%$ by volume. Life-cycle analysis indicates that the use of biodiesel can help displace imported petroleum in the United States, and resource assessments have indicated that biodiesel has the potential to displace $5 \%$ or more of petroleum diesel over the next decade $[2,3]$. However, because biodiesel has a relatively higher 
distillation temperature and boiling point, when it is present in post-injected fuel it tends to dilute the oil on a level disproportionate to its blend ratio in the fuel $[4,5$, $6]$. This leads to a concern about oil dilution.

Current research at the National Renewable Energy Laboratory (NREL) on the impacts of biodiesel on emission control systems has provided an opportunity to also evaluate the impact of biodiesel fuel blends on oil dilution and its associated impacts on the performance of the engine and emission control system. As a corollary to a larger research project at NREL on biodiesel impacts on selective catalytic reduction (SCR) with urea and oxides of nitrogen $\left(\mathrm{NO}_{\mathrm{x}}\right)$ adsorber catalyst (NAC) systems [7, 8], researchers assessed biodiesel's impacts on oil dilution. The purpose of this paper is to document the oil dilution observed in this research project and assess any potential engine or emission control system impacts.

\section{HARDWARE DESCRIPTION}

The following sections provide an overview of the hardware components used during the project. The test vehicle and test engines were procured by the U.S. Department of Energy in direct support of this project. All the catalyst hardware, as well as the urea dosing system, was supplied by the Manufacturers of Emissions Controls Association (MECA).

ENGINE HARDWARE - The engine used for this project in the test cell as well as in the vehicle was a 4-cylinder $2.15 \mathrm{~L}$ high-speed direct injection (HSDI) diesel engine. The original engine calibration complied with Euro 4 emission standards. The engine utilized a conventional high-pressure exhaust gas recirculation (EGR) loop, a second-generation common-rail fuel injection system (1600 bar maximum injection pressure, solenoid injectors) with all actuators electrically controlled. Table 1 lists the main parameters of the test engine.

Table 1: Engine specifications

\begin{tabular}{|l|l|}
\hline Engine Power & $113 \mathrm{~kW}$ at $4000 \mathrm{rpm}$ \\
\hline Peak Torque & $360 \mathrm{Nm}$ at $2000 \mathrm{rpm}$ \\
\hline Maximum Engine Speed & $4700 \mathrm{rpm}$ \\
\hline Maximum BMEP & $21 \mathrm{bar}$ \\
\hline Cylinder Arrangement & $4-$ Cylinder Inline \\
\hline Firing Order & $1-3-4-2$ \\
\hline Valve Train & 4 Valve DOHC \\
\hline Bore to Stroke Ratio & 1.0034 \\
\hline Displacement & $2.15 \mathrm{~L}$ \\
\hline Compression Ratio & $18: 1$ \\
\hline Fuel Injection System & $2^{\text {nd }}$ Generation Common Rail \\
\hline
\end{tabular}

The test vehicle was a conventional four-door sedan vehicle in the $1,700 \mathrm{~kg}$ class. It met the Euro 4 emission standards and was equipped with a catalyzed diesel particle filter (DPF) as a standard feature. Table 2 lists the relevant vehicle features.

Table 2: Vehicle specifications

\begin{tabular}{|l|c|c|}
\hline \multicolumn{1}{|c|}{ Criterion } & Unit & Value \\
\hline Vehicle Mass & $\mathrm{kg}$ & 1,700 \\
\hline Air Drag Coefficient & - & 0.29 \\
\hline Frontal Surface Area & $\mathrm{m}^{2}$ & 2.20 \\
\hline Transmission Gear Ratio & $1^{\text {st }}$ & 4.99 \\
\hline \multirow{5}{*}{} & $2^{\text {nd }}$ & 2.82 \\
\cline { 2 - 3 } & $3^{\text {rd }}$ & 1.78 \\
\cline { 2 - 3 } & $4^{\text {th }}$ & 1.25 \\
\cline { 2 - 3 } & $5^{\text {th }}$ & 1.00 \\
\cline { 2 - 3 } & $6^{\text {th }}$ & 0.82 \\
\cline { 2 - 3 } & Axle & 2.65 \\
\hline Tires & Rear & $205 / 55 \mathrm{R} 1691 \mathrm{H}$ \\
\hline & Front & $205 / 55 \mathrm{R} 1691 \mathrm{H}$ \\
\hline
\end{tabular}

CATALYST SPECIFICATIONS - Two emission control systems (ECS) were developed and tested separately as part of this project. These included an NAC/DPF system and a SCR/DPF system. The NAC was located in a close-coupled position, directly after the turbine exit with minimal distance to the catalyst to allow for rapid heat-up of this $\mathrm{NO}_{\mathrm{x}}$ treatment unit; the DPF was located under the floor. The SCR catalyst was also located under the floor and was followed by the DPF in the same can, with a close-coupled diesel oxidation catalyst (DOC). All the piping between the DOC exit and the SCR inlet was made of dual-wall exhaust pipe to increase heat preservation during operation. MECA provided all the ECS components. Table 3 lists all the catalyst specifications for this project.

Table 3: Catalyst specifications for each component

\begin{tabular}{|l|l|l|l|l|}
\hline \multicolumn{2}{|c|}{ Component System } & $\begin{array}{c}\text { Volume } \\
{[\mathrm{L}]}\end{array}$ & $\begin{array}{c}\text { Cell } \\
\text { Density } \\
{[\mathrm{cpsi}]}\end{array}$ & $\begin{array}{c}\text { PGM } \\
\text { loading } \\
{\left[\mathrm{g} / \mathrm{ft}^{3}\right]}\end{array}$ \\
\hline $\begin{array}{l}\text { NAC } \\
\text { System }\end{array}$ & DOC & 0.8 & 400 & 150 \\
\cline { 2 - 5 } & DPF & 3.3 & 300 & 60 \\
\cline { 2 - 5 } & NAC & 4.1 & 400 & 120 \\
\hline $\begin{array}{l}\text { SCR } \\
\text { System }\end{array}$ & DOC & 1.23 & 400 & 150 \\
\cline { 2 - 5 } & DPF & 4.1 & 300 & 60 \\
\cline { 2 - 5 } & SCR Fe-ZSM-5 & 4.43 & 300 & N/A \\
\hline
\end{tabular}

FUEL AND OIL SPECIFICATIONS - An ultra-low-sulfur diesel fuel (ULSD), also referred to as the base fuel, was used to blend the $20 \%$ by volume soy-derived methyl ester. Table 4 lists the fuel specifications for each tested fuel type. The effects on the fuel specifications as a result of the increased amount of methyl ester become particularly noticeable in the heating value, the cetane number, and the oxygen content. The base lube oil used for this study was CJ-4 oil. 
Table 4: Fuel specifications

\begin{tabular}{|l|c|c|c|c|}
\hline Specification & Unit & $\begin{array}{c}\text { ASTM } \\
\text { Method }\end{array}$ & ULSD & B20 \\
\hline $\begin{array}{l}\text { Net Heating } \\
\text { Value }\end{array}$ & $\mathrm{MJ} / \mathrm{kg}$ & $\mathrm{D} 240$ & 42.53 & 41.52 \\
\hline $\begin{array}{l}\text { Cetane } \\
\text { Number }\end{array}$ & - & $\mathrm{D} 6890$ & 41.4 & 45.6 \\
\hline $\begin{array}{l}\text { Density at } \\
15^{\circ} \mathrm{C}\end{array}$ & $\mathrm{kg} / \mathrm{m}^{3}$ & $\mathrm{D} 4052$ & 847.5 & 852.9 \\
\hline $\begin{array}{l}\text { Viscosity at } \\
40^{\circ} \mathrm{C}\end{array}$ & $\mathrm{mm}^{2} / \mathrm{sec}$ & $\mathrm{D} 445$ & 2.429 & 2.685 \\
\hline $\begin{array}{l}\text { Carbon } \\
\mathrm{wt} \%\end{array}$ & $\mathrm{D} 5291$ & 87.04 & 85.01 \\
\hline Oxygen & $\mathrm{wt} \%$ & $\begin{array}{c}\mathrm{By} \\
\text { difference }\end{array}$ & 0.00 & 2.29 \\
\hline Hydrogen & $\mathrm{wt} \%$ & $\begin{array}{c}\mathrm{D} 5291 \\
12.96\end{array}$ & 12.70 \\
\hline
\end{tabular}

\section{LATE IN-CYLINDER FUEL INJECTION EVENTS}

Oil dilution in diesel engines will occur over time with normal operation, leading to oil degradation and the need for oil replacement. With increased use of advanced emission control devices, oil dilution impacts can also increase as a result of late in-cylinder fuel injection events used in conjunction with some of these devices $[4,6]$. The late injection events are used as a regeneration strategy for DPFs as well as NACs. These late injection events increase the opportunity for unburned fuel to reach the cylinder walls and in turn enter the lubricating oil. With conventional diesel fuel it can boil out of the lube oil, minimizing long-term dilution effects. However, this effect is accentuated with biodiesel because of its high boiling point relative to petroleum diesel, which can lead to a disproportionate amount of fuel being retained in the lube oil. Three main late injection events are associated with DPF and NAC operation that can accentuate the oil dilution problem. These include lean-rich modulation used for NAC regeneration, desulfurization used to liberate the NAC from accumulated fuel-borne sulfur, and DPF regeneration used to burn off accumulated soot from the DPF substrate.

LEAN-RICH MODULATION - NAC regeneration is a key component of meeting $\mathrm{NO}_{x}$ emission standards with an NAC system. A short pulse of rich exhaust gas desorbs the $\mathrm{NO}_{\mathrm{x}}$ emissions and subsequently reduces them, following the well-known chemistry of the three-way catalyst, described in more detail in the next section. These events occur quite frequently (e.g., every one to two minutes). The goal is to obtain the required rich exhaust conditions with a diesel engine that typically operates under lean conditions. Lean-rich modulation through late in-cylinder fuel injection is used to achieve the rich exhaust conditions required by the NAC, but this also has the potential to lead to increased oil dilution.

Desulfurization - The basic principle of NAC is the adsorption of $\mathrm{NO}_{2}$ during the lean operating phases of the engine. The $\mathrm{NO}_{2}$ is adsorbed by alkaline earth oxides forming nitrates such as $\mathrm{Ba}\left(\mathrm{NO}_{3}\right)_{2}$. The nitrates become unstable and release the $\mathrm{NO}$ and $\mathrm{NO}_{2}$ at high temperature (thermal release of $\mathrm{NO}_{\mathrm{x}}$ ) or during rich exhaust conditions. The rich exhaust conditions allow the three-way-catalyst mechanism to be used to reduce the released $\mathrm{NO}_{\mathrm{x}}$ into $\mathrm{N}_{2}$ and $\mathrm{CO}_{2}$. In addition to their desired functions, NACs exhibit the undesired function of adsorbing $\mathrm{SO}_{3}^{-2}$ and forming $\mathrm{BaSO}_{4}$, which is a considerably more stable compound requiring high temperatures and stoichiometric operating conditions to be released. This release or desulfurization has to occur relatively frequently to avoid catalyst deactivation. The frequency of this event depends on the fuel sulfur level as well as the contribution of the engine lubricating oil. The rich operation required to create these hightemperature desulfurization conditions also requires late in-cylinder fuel injection, and that in turn creates an opportunity for increased oil dilution.

DPF REGENERATION - DPF regeneration is occasionally required in order to oxidize the accumulated soot that collects on the DPF during normal engine operation. As with NAC regeneration and NAC desulfurization, late in-cylinder fuel injection is used to create the high temperatures over the DPF required to burn or oxidize the accumulated soot. This provides another opportunity for increased oil dilution, and it would be the case for both NAC systems and SCR systems.

\section{AGING TEST CYCLE}

Both systems were aged to an equivalent of 120,000 miles, or full useful life, and the oil was sampled at regular intervals during this aging. In order to simulate the appropriate aging conditions, the engine and ECS were exposed to an equivalent useful lifetime of fuel in the engine dynamometer test cell. To keep the aging time at a reasonable level, the aging duration for each ECS was set to be accomplished in approximately 700 hours. The following assumptions were used regarding fuel consumption for the system:

- Highway Fuel Economy Test (HFET) fuel economy of $55 \mathrm{mpg}$

- Urban Dynamometer Driving Schedule (UDDS) cycle fuel economy of $33 \mathrm{mpg}$

- Split of $3 / 4$ HFET and $1 / 4$ UDDS

These assumptions resulted in an average fuel economy of $49.5 \mathrm{mpg}$. At 120,000 miles, this equates to 2,424 gallons or $7,708 \mathrm{~kg}$ of fuel. Given the 700 hours of aging time, an average fuel consumption of approximately 11 
$\mathrm{kg} / \mathrm{hr}$ was established. Three operating phases were established to reflect real in-use operating modes:

1. NAC operation using the systems efficiency control algorithms to determine the frequency of regeneration events

2. DPF regeneration (300 for full useful life, 20 minutes each)

3. Desulfurization (25 for full useful life for the NAC system only, 20 minutes each)

Table 5 shows detailed operating conditions and durations for the chosen durability cycle. In phase 1, the engine operating conditions are changed between two operating points (OP1 and OP2) for 120 minutes and repeated 300 times. In phase 2 , the system transitioned into the DPF regeneration mode with a DPF inlet temperature set point of $650^{\circ} \mathrm{C}$. Once the DPF regeneration was completed, approximately 20 minutes, the system returned to phase 1 operation. This sequence was repeated until the total runtime of 28 hours was achieved. After 28 hours, the system was forced into the phase 3 desulfurization mode with a set point temperature of $700^{\circ} \mathrm{C}$ and frequent lean-rich transitions, as discussed in the desulfurization section. The entire sequence of (phase 1 plus phase 2) x 12 plus phase 3 was repeated 25 times to add up to the total run time of just over 700 hours. Phase 3 was run only with the NAC system as desulfurization was not required for the SCR system. In addition to the operating points, the following table also contains the fuel flow rates for each state.

Table 5: Durability cycle operating conditions

\begin{tabular}{|c|c|c|c|c|}
\hline $\begin{array}{c}\text { Operating } \\
\text { Point }\end{array}$ & $\begin{array}{l}\text { Operating } \\
\text { Condition }\end{array}$ & Duration & Reps & $\begin{array}{c}\text { Fuel } \\
\text { Consumed }\end{array}$ \\
\hline & [rpm or Nm] & [min.] & & [gallons] \\
\hline OP 1 & $\begin{array}{l}2000 \mathrm{rpm}, \\
210 \mathrm{Nm}\end{array}$ & 5 & & 0.262 \\
\hline OP 2 & $\begin{array}{l}2600 \mathrm{rpm}, \\
160 \mathrm{Nm}\end{array}$ & 5 & & 0.287 \\
\hline Phase 1 & $\begin{array}{l}(\mathrm{OP} 1+\mathrm{OP} 2) \\
\times 12\end{array}$ & 120 & 300 & 6.234 \\
\hline Phase 2 & $\begin{array}{l}\text { DFP } \\
\text { regeneration } \\
2600 \mathrm{rpm} \text {, } \\
110 \mathrm{Nm}\end{array}$ & 20 & 300 & 1.062 \\
\hline $\begin{array}{l}\text { Total per } \\
\text { Cycle }\end{array}$ & $\begin{array}{l}\text { Phase } 1+ \\
\text { Phase } 2\end{array}$ & 140 & 300 & 7.296 \\
\hline $\begin{array}{l}\text { Phase } 3 \\
\text { (NAC } \\
\text { only) }\end{array}$ & $\begin{array}{l}\text { Desulfurization } \\
2200 \mathrm{rpm}, \\
75 \mathrm{Nm}\end{array}$ & 20 & 25 & 0.668 \\
\hline
\end{tabular}

\section{OIL ANALYSIS METHODOLOGY}

The fatty acid methyl ester (FAME) content in the vehicle's lube oil was determined using a modified version of ASTM D7371, which covers FAME content in diesel fuel oil. Infrared spectroscopy was performed using a Thermo Scientific Nicolet 4700 Fourier transform infrared (FTIR) instrument equipped with a zinc-selenide (ZnSe) $60^{\circ}$ attenuated total reflectance (ATR) cell. Samples were prepared by diluting the lube oil $50 \%$ by volume in heptane, which helped to make the sample cleanup of the ATR cell easier. The FTIR was calibrated with six standards made from a typical soy-derived biodiesel and the unused lube oil from the project. The standards ranged from $0 \%-9 \%$. The calibration and samples were analyzed by comparing biodiesel specific peak intensities over the ranges of $1188-1340 \mathrm{~cm}-1$ and 1724-1751 cm-1. A partial least squares (PLS) calibration was developed using the TQ Analyst software package, version 7.2 Each sample was collected using 32 scans and a 2 wave-number resolution. Four standard checks were performed to verify calibration from both soy- and animal-derived FAMEs. Recoveries of these checks averaged $106 \%$. Repeatability was acceptable; each of the 19 samples was run twice, and all showed an average variation of $5 \%$. Sample matrix spiking done on 19 different samples showed an average recovery of $88 \%$. The JPI5S23 method was used to measure the petroleum diesel fuel oil dilution in each sample.

Additionally, the used oil samples were tested for viscosity at $100^{\circ} \mathrm{C}$ (D445), total base number (TBN via D4739), total acid number (TAN via D664), and metals by inductively coupled plasma (ICP) (D5185).

\section{OIL DILUTION RESULTS}

The following section describes the oil dilution observations made at several points during the aging of each ECS; the oil was sampled and analyzed during each oil change. The biodiesel oil dilution figures in this section are based on measurements made using the methodology described above.

For the NAC systems, the oil sample/change interval started at $\sim 50$ hours at the start of aging (approximately every 10,000 miles) and then changed to $\sim 100$ hours toward the end of aging (approximately every 20,000 miles). This was done to better understand the impact of extended oil change events. Table 6 shows the oil dilution measurements for the NAC systems along with the sample/change interval and the total ECS age. 
Table 6: Oil dilution measurements for the NAC system

\begin{tabular}{|c|c|c|c|c|}
\hline $\begin{array}{c}\text { Sample } \\
\#\end{array}$ & $\begin{array}{c}\text { Oil Age } \\
\text { (hours) }\end{array}$ & $\begin{array}{c}\text { System } \\
\text { Age } \\
\text { (hours) }\end{array}$ & $\begin{array}{c}\text { Biodiesel } \\
\text { Oil } \\
\text { Dilution } \\
(\%)\end{array}$ & $\begin{array}{c}\text { Diesel } \\
\text { Oil } \\
\text { Dilution } \\
(\%)\end{array}$ \\
\hline 1 & 48 & 48 & 4.7 & 2.9 \\
\hline 2 & 92 & 140 & 6.6 & 3.4 \\
\hline 3 & 65 & 205 & 5.2 & 4.2 \\
\hline 4 & 90 & 295 & 5.7 & - \\
\hline 5 & 67 & 362 & 5.3 & 2.0 \\
\hline 6 & 65 & 427 & 6.8 & 3.0 \\
\hline 7 & 65 & 492 & 5.9 & 2.7 \\
\hline 8 & 100 & 592 & 8.3 & 3.5 \\
\hline 9 & 158 & 750 & 10.1 & 4.1 \\
\hline
\end{tabular}

As Table 6 shows, biodiesel oil dilution levels for the NAC system ranged from less than $5 \%$ to $10 \%$; the highest measurements were associated with longer oil change intervals that occurred at the end of the aging. Each oil sample was exposed to numerous late incylinder fuel injection events for NAC and DPF regeneration and NAC desulfurization. NAC regeneration events were the most frequent, ranging from 605 to 2,010 events per oil change. The DPF regeneration events ranged from 21 to 65 per oil change event, and the desulfurization events occurred only a few times per oil change. Figure 1 shows the number of late in-cylinder fuel injection events by category. A comparison of this figure with Table 6 shows that biodiesel oil dilution levels track with the frequency of late in-cylinder injection events, but also with oil age.

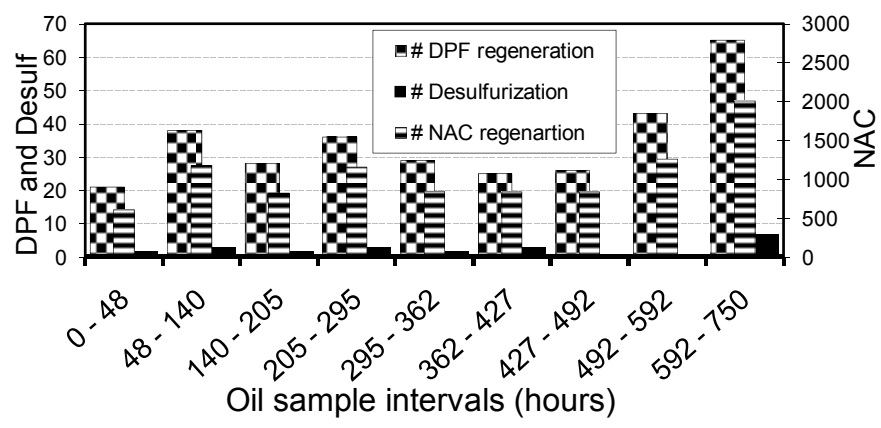

Figure 1: Late in-cylinder fuel injection events by category as a function of ECS age
Viscosity decreased with increasing oil age and increasing diesel fuel dilution, but it never went below 11 cSt. TBN decreased sharply with oil age, getting as low as $2.44 \mathrm{mg} \mathrm{KOH} / \mathrm{g}$ for 150 -hour oil, while TAN increased slightly to $2.26 \mathrm{mg} / \mathrm{KOH} / \mathrm{g}$. Iron in the oil increased with age, reaching a level of $55 \mathrm{ppm}$ at 150 hours. Lead was below detection except for samples exceeding 100 hours in age, where it was $3 \mathrm{ppm}$.

For the SCR systems, the oil sample/change interval started at $\sim 50$ hours and remained at that interval for the entire aging process (approximately every 10,000 miles). Table 7 shows the oil dilution measurements for the SCR systems along with the oil sample/change interval and the total ECS age.

Table 7 shows that the biodiesel oil dilution levels for the SCR systems range from less than $4 \%$ to $8 \%$. As shown in Figure 2, the biodiesel oil dilution levels for the SCR system, relative to oil age, are similar to those associated with the NAC system. This result was observed despite the fact that the SCR system was exposed to far fewer late in-cylinder fuel injection events. The SCR system was exposed to only 16 to 27 late incylinder fuel injection events, depending on the oil change sample/interval. These events were associated with the DPF regeneration. It appears that oil age, and not late in-cylinder fuel injection events, is the driving factor in determining biodiesel oil dilution levels.

Used oil age never exceeded 80 hours for the SCR system. Viscosity was approximately constant for the used oils, at about $13.9 \mathrm{cSt}$. TBN decreased slightly with oil age, reaching a low value of $4.54 \mathrm{mg} / \mathrm{KOH} / \mathrm{g}$ at 75 hours, while TAN was essentially constant at about 2 $\mathrm{mg} / \mathrm{KOH} / \mathrm{g}$. Iron in the oil increased with oil age but never exceeded $12 \mathrm{ppm}$; other wear metals were below detection limits.

The main observations are a significant reduction in TBN for the lubricant in both systems and a higher level of iron in used lubricant for the NAC system. The researchers anticipate that biodiesel in the lubricant will oxidize to produce acids, causing a reduction in TBN. Biodiesel content in the oil increases with oil age for both the NAC system and the SCR system. Figure 3 shows that the rate of TBN decrease with oil age is identical for the SCR and NAC systems, indicating that the main factor affecting TBN loss is simply lubricant age, not biodiesel content. TAN never exceeds TBN, indicating that even up to 150 hours the lubricant service interval had not been exceeded. 
Table 7: Oil dilution measurements for SCR system

\begin{tabular}{|c|c|c|c|c|}
\hline $\begin{array}{c}\text { Sample } \\
\#\end{array}$ & $\begin{array}{c}\text { Oil Age } \\
\text { (hours) }\end{array}$ & $\begin{array}{c}\text { System } \\
\text { Age } \\
\text { (hours) }\end{array}$ & $\begin{array}{c}\text { Biodiesel } \\
\text { Oil } \\
\text { Dilution } \\
(\%)\end{array}$ & $\begin{array}{c}\text { Diesel } \\
\text { Oil } \\
\text { Dilution } \\
(\%)\end{array}$ \\
\hline 1 & 65 & 65 & 8.0 & 4.6 \\
\hline 2 & 76 & 141 & 7.6 & 4.0 \\
\hline 3 & 54 & 195 & 6.5 & 3.1 \\
\hline 4 & 65 & 260 & 7.0 & 3.3 \\
\hline 5 & 59 & 319 & 4.1 & 1.6 \\
\hline 6 & 63 & 382 & 4.7 & 1.8 \\
\hline 7 & 58 & 440 & 4.1 & 1.6 \\
\hline 8 & 64 & 504 & 3.7 & 1.0 \\
\hline 9 & 64 & 568 & 3.6 & 1.0 \\
\hline 10 & 45 & 613 & 3.7 & 1.4 \\
\hline
\end{tabular}

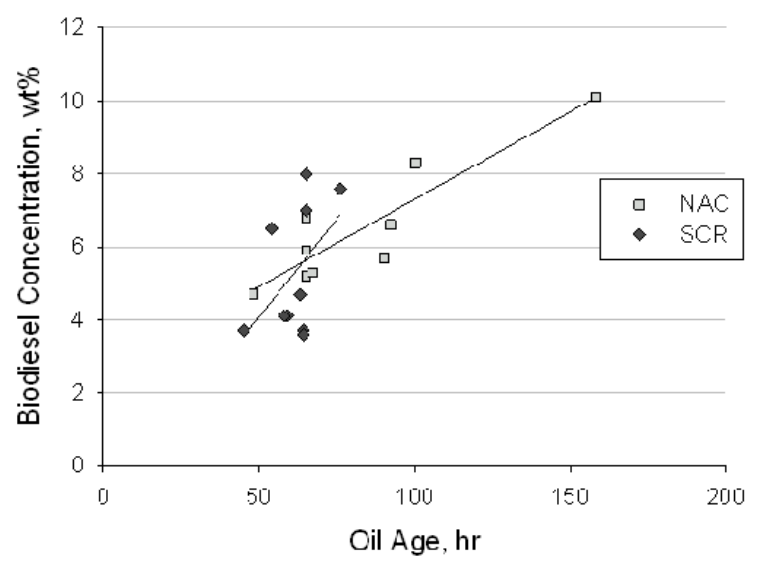

Figure 2: Lubricant biodiesel content as a function of lubricant age

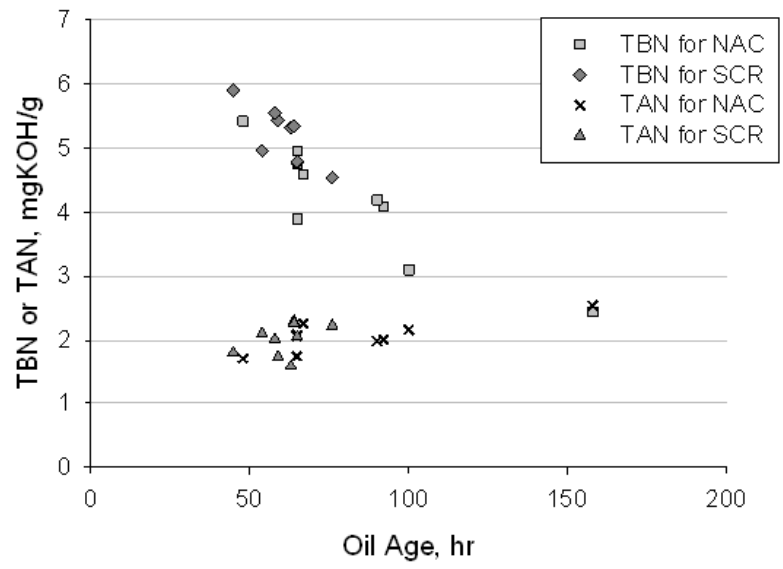

Figure 3: TBN and TAN as a function of lubricant age for both systems

\section{EMISSIONS IMPACTS}

At two points, during and after the completion of the durability testing with each ECS, the components were installed in the project vehicle and underwent emissions testing. All of the following vehicle tests were conducted at EPA's National Vehicle and Fuel Emissions Laboratory. The vehicle was tested using a 48-inchdiameter, single-roll, electric chassis dynamometer. The tests showed that Tier 2 Bin 5 emission levels could be met with the NAC ECS. However, the performance of the SCR system degraded to a point at which Tier 2 Bin 5 limits could not be met. Figure 4 and Table 8 show the system performance in the course of the aging process for both ECS.
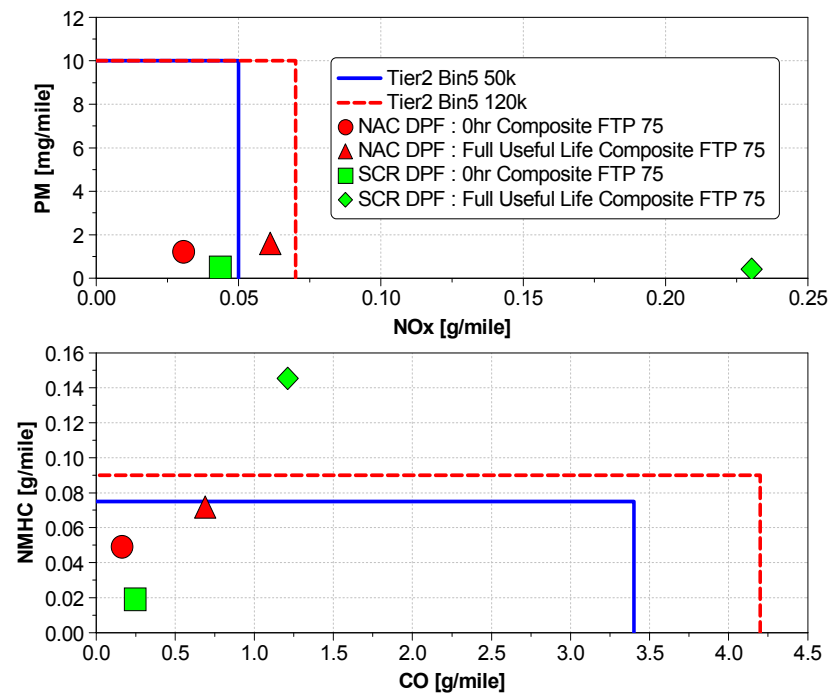

Figure 4: Emission results with new and useful life aged components

Although the desired $\mathrm{NO}_{x}$ and $\mathrm{NMHC}$ emission levels for the SCR system were not met, the researchers believe that this was the result of degradation of the SCR catalyst from thermal shock due to hydrocarbon $(\mathrm{HC})$ adsorption and loss of cold start performance, and not a result of fuel or fuel oil dilution impacts. The Tier 2 Bin 5 emission levels could be met with the SCR system for $\mathrm{PM}$ and $\mathrm{CO}$.

Table 8: Emission results with new and useful life aged components, FTP 75 (g/mi)

\begin{tabular}{|l|c|c|c|c|}
\hline \multicolumn{1}{|c|}{ System } & $\mathrm{NO}_{\mathrm{x}}$ & $\mathrm{PM}$ & $\mathrm{CO}$ & $\mathrm{NMHC}$ \\
\hline NAC $0 \mathrm{hr}$ & 0.031 & 0.0012 & 0.163 & 0.149 \\
\hline NAC $700 \mathrm{hr}$ & 0.061 & 0.0016 & 0.690 & 0.072 \\
\hline SCR $0 \mathrm{hr}$ & 0.044 & 0.0005 & 0.247 & 0.019 \\
\hline SCR $700 \mathrm{hr}$ & 0.230 & 0.0004 & 1.212 & 0.145 \\
\hline
\end{tabular}




\section{ENGINE COMPONENT IMPACTS}

After the completion of the durability tests for the NAC and the SCR system, the engine had undergone an accelerated aging schedule representative of twice its useful life, or approximately 240,000 miles. At the conclusion of the project, the engine was disassembled and each component was carefully analyzed. All moving parts such as bearings, pistons, and piston rings were inspected and measured. None of the components of the engine, including the injectors, showed signs of excessive wear or other signs of deterioration as a result of the extended biodiesel operation. The flow characteristics of the injectors remained comparable to levels noted before the start of the durability study. Figure 5 shows several engine components after the disassembly.

The cylinder bore in the upper left corner of Figure 5 shows the honing pattern, which indicates that there was no loss in oil control for this engine. The main bearing shown below the cylinder bore showed no sign of deterioration or wear. This component is prone to wear caused by oil dilution and the resulting loss in lubricity of the engine oil. On the main journal as well as one cam, shown on the right side of the figure, no visible signs of wear were detected.
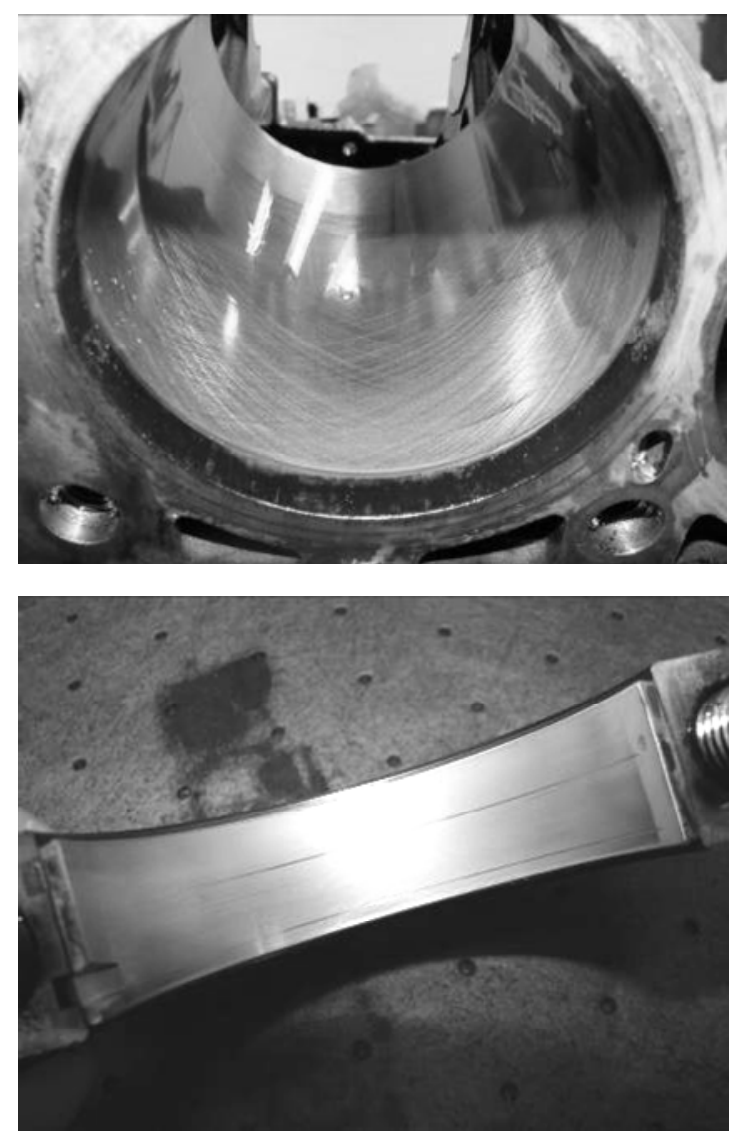

\section{CONCLUSION}

The completed project included an evaluation of two emission control systems tested in conjunction with a biodiesel blend fuel. The focus of this paper was on the biodiesel oil dilution levels observed for both systems utilizing a $20 \%$ biodiesel blend. For the NAC system (which requires a late in-cylinder fuel injection for regeneration), the biodiesel oil dilution level ranged from $5 \%-10 \%$ for oil samples ranging in age from $\sim 50$ to $\sim 150$ hours. For the SCR system (which used a urea solution as a reductant and required only late in-cylinder fuel injection for DPF regeneration), biodiesel oil dilution ranged from $<4 \%-8 \%$ for oil samples ranging in age from $\sim 50$ to $\sim 75$ hours. The rate of biodiesel accumulation in the oil as a function of oil age was similar for both ECS, despite the fact that the SCR system saw fewer late in-cylinder fuel injection events. There were no obvious biodiesel specific effects on used lube oil properties, and most changes appeared to be consistent with normal lube oil aging. Based on a comparison of TBN and TAN, oil service life was never exceeded in these tests. Despite these biodiesel oil dilution levels, no impacts were observed on the performance of the engine or the emission control systems.
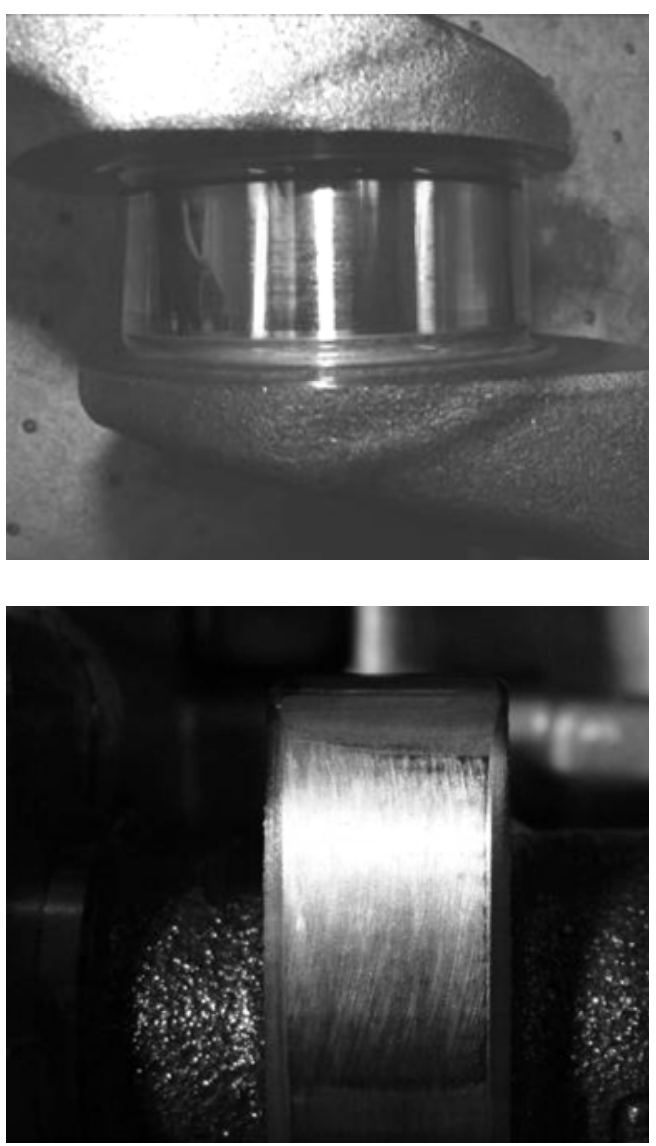

Figure 5: Selected engine components 
Durability tests with both emission control systems [8] demonstrated that the NAC system provides sustainable conversion efficiencies over its useful life. However, the SCR system did experience performance degradation, which was attributed to the deactivation of the ironzeolite through thermal shock.

Finally, no biodiesel-related wear and engine mechanics deterioration were found after the hardware was exposed to an accelerated aging protocol of twice the engine's useful life.

\section{ACKNOWLEDGMENTS}

The authors express their gratitude to all the team members who supported the project and contributed to all the technical discussions.

This work was supported jointly by the U.S. Department of Energy (DOE) Office of Vehicle Technologies and by the National Biodiesel Board (NBB). Special thanks to Kevin Stork and Dennis Smith of DOE and to Steve Howell at the NBB.

The authors also acknowledge Joe Kubsh and Rasto Brezny of MECA and team members for the in-kind contributions of all exhaust ECS hardware, Charles Schenk of the U.S. EPA for providing access to the chassis dynamometer for the vehicle tests, and Harsha Nanjundaswamy and Marek Tatur of FEV Incorporated for managing the testing program.

\section{REFERENCES}

1. R. Kotrba, "Understanding the Post-Injection Problem," Biodiesel Magazine, Vol. 5, No. 5, May 2008.

2. John Sheehan, Vince Camobreco, James Duffield, Michael Graboski, and Housein Shapouri, An Overview of Biodiesel and Petroleum Diesel Life Cycles, NREL/TP-580-24772, May 1998.

3. K. S. Tyson, J. Bozell, R. Wallace, E. Petersen, and L. Moens, Biomass Oil Analysis: Research Needs and Recommendations. NREL/TP-510-34796. Golden, CO: National Renewable Energy Laboratory, June 2004.

4. Andrea Morgan, Howard Fang, and Bhandary Kirtan, "Biodiesel on Fuel Dilution of Engine Oil," SAE 2007-01-4036.

5. Cathy C. Devlin, Charles Passut, Tze-Chi Jao, and Bob Campbell, "Biodiesel Fuel Effect on Diesel Engine Lubrication," SAE 2008-01-2375.

6. Howard Fang, Shawn Whitacre, Elaine Yamaguchi, and Maarten Boons, "Biodiesel Impact on Wear Protection of Engine Oils," SAE 2007-01-4141.
7. Marek Tatur, Harsha Nanjundaswamy, Dean Tomazic, and Matthew Thornton, "Biodiesel Effects on U.S. Light-Duty Tier 2 Engine and Emission Control Systems," SAE 2008-01-0080.

8. Marek Tatur, Harsha Nanjundaswamy, Dean Tomazic, and Matthew Thornton, "Biodiesel Effects on U.S. Light-Duty Tier 2 Engine and Emission Control Systems-Part 2," SAE 2009-01-0281.

\section{CONTACT}

Matthew Thornton, Senior Engineer, National Renewable Energy Laboratory (NREL), matthew.thornton@nrel.gov.

\section{DEFINITIONS, ACRONYMS, ABBREVIATIONS}

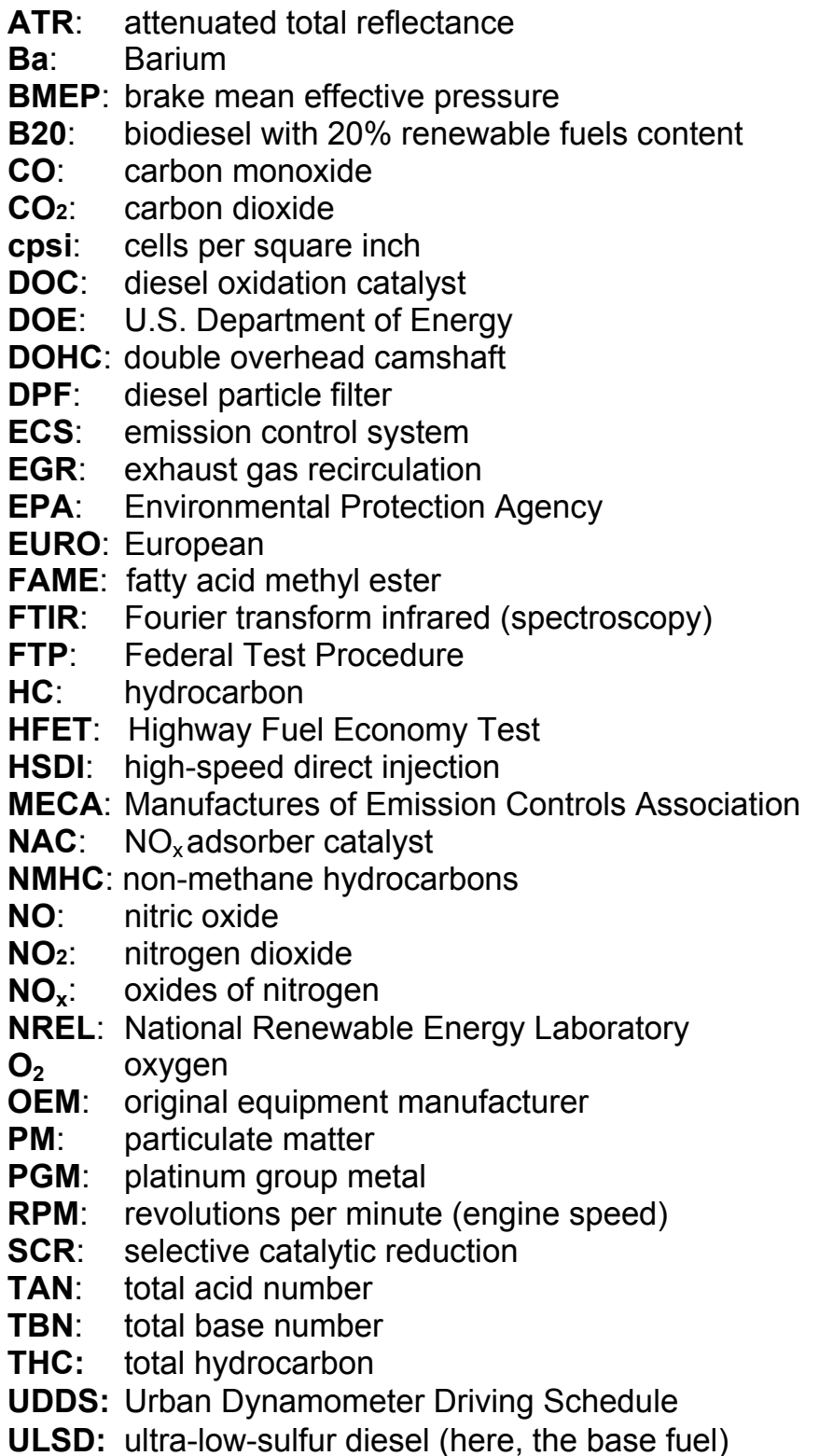




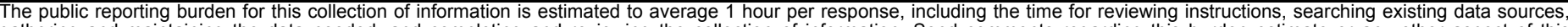

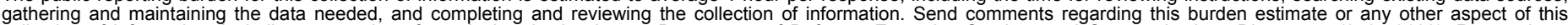

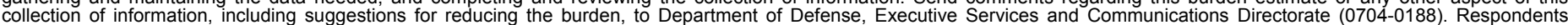

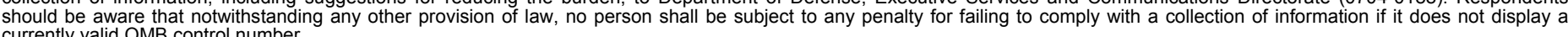

PLEASE DO NOT RETURN YOUR FORM TO THE ABOVE ORGANIZATION.
1. REPORT DATE (DD-MM-YYYY) August 2009
4. TITLE AND SUBTITLE
Impacts of Biodiesel Fuel Blends Oil Dilution on Light-Duty Diesel Engine Operation

3. DATES COVERED (From - To)

5a. CONTRACT NUMBER

DE-AC36-08-GO28308

5b. GRANT NUMBER

5c. PROGRAM ELEMENT NUMBER

5d. PROJECT NUMBER

NREL/CP-540-44833

5e. TASK NUMBER

FC089400

5f. WORK UNIT NUMBER
7. PERFORMING ORGANIZATION NAME(S) AND ADDRESS(ES)

National Renewable Energy Laboratory

1617 Cole Blvd.

Golden, CO 80401-3393

\section{PERFORMING ORGANIZATION REPORT NUMBER \\ NREL/CP-540-44833}

9. SPONSORING/MONITORING AGENCY NAME(S) AND ADDRESS(ES)

\section{SPONSOR/MONITOR'S ACRONYM(S)} NREL

11. SPONSORING/MONITORING AGENCY REPORT NUMBER

12. DISTRIBUTION AVAILABILITY STATEMENT

National Technical Information Service

U.S. Department of Commerce

5285 Port Royal Road

Springfield, VA 22161

13. SUPPLEMENTARY NOTES

14. ABSTRACT (Maximum 200 Words)

This paper assesses the oil dilution impacts on an engine operating in conjunction with a diesel particle filter (DPF), oxides of nitrogen (NOx) storage, a selective catalytic reduction (SCR) emission control system, and a $20 \%$ soybased biodiesel fuel blend. The focus was on biodiesel oil dilution levels observed during an accelerated aging protocol and an assessment of the potential impacts on the engine and emissions control systems. For the NOx storage system, which requires a late in-cylinder fuel injection for regeneration, biodiesel oil dilution levels ranged from $5 \%$ to $10 \%$. For the SCR system, which used a urea solution as a reductant and late in-cylinder fuel injection for DPF regeneration, biodiesel oil dilution ranged from $<4 \%$ to $8 \%$, as observed over typical oil drain intervals. Despite observed biodiesel oil dilution levels, no impacts were observed on engine performance or emission control systems.

15. SUBJECT TERMS

biodiesel fuel; diesel engine; fuel oil dilution; diesel emissions; diesel particle filter; selective catalytic reduction; emission control system

\begin{tabular}{l} 
16. SECURITY CLASSIFICATION OF: \\
\begin{tabular}{|l|l|l|}
\hline $\begin{array}{l}\text { a. REPORT } \\
\text { Unclassified }\end{array}$ & b. ABSTRACT & c. THIS PAGE \\
& Unclassified & Unclassified \\
\hline
\end{tabular} \\
\hline
\end{tabular}

\begin{tabular}{l|l|}
$\begin{array}{l}\text { 17. LIMITATION } \\
\text { OF ABSTRACT }\end{array}$ & $\begin{array}{l}\text { 18. } \\
\text { NUMBER } \\
\text { OF PAGES }\end{array}$ \\
UL & \\
\end{tabular}

19a. NAME OF RESPONSIBLE PERSON

19b. TELEPHONE NUMBER (Include area code) 